\title{
The Tie That Snapped: Bubonic Plague and Mill Labour in Bombay, I 896-1898
}

\author{
A DITYA SARKAR \\ Department of History, University of Warwick \\ Humanities Building, University Road, Coventry, $C V_{4} 7 A L$, \\ United Kingdom
}

E-mail: Aditya.Sarkar@warwick.ac.uk

\begin{abstract}
AвSTRACT: In September i896, the city of Bombay witnessed the beginning of a long-drawn-out epidemic crisis, with the outbreak of bubonic plague. This article investigates one particular dimension of this crisis - its effects upon the city's cotton textile mills, and its profound, though temporary, alteration of the relations between employers and workers. It argues that the structure of industrial relations in the textile mills in the second half of the nineteenth century rested upon the retention of wage arrears by mill managements, which forced workers into permanent debt, and bound them to the mill and their employers. The demographic and industrial crisis ushered in during the plague years, the article shows, cracked open this structure of industrial control, and workers were able to sustain a new, fleeting system of industrial "regulation from below", based on the daily payment of wages. Through a study of the tensions in textile mills in I897, situated within the broader context of a crisis of urban labour relations, the article shows the ways in which industrial relations were both deconstructed and reconstituted in a new form.
\end{abstract}

In September I896, Bombay's municipal administration declared the presence of bubonic plague in the city. ${ }^{\mathrm{I}}$ Within weeks, a series of ramshackle medical and sanitary fortifications against the epidemic had been erected, but these proved ineffective. In the winter of that year, the plague toll rose dramatically, and by March I 897 over I0,000 lives had been lost, despite an array of draconian measures of plague control. ${ }^{2}$

Correspondingly, a "popular panic" gripped the city, as much in response to the administration's attempts to survey, control, and attack the bodies and congested neighbourhoods of the city's working poor as to

I. Abstract of Report of the Sanitary Commissioner with the Government of India for I 896, in Report on Sanitary Measures in India [hereafter, RSM] in I 896-97, XXX, p. I05.

2. Abstract of Report of the Sanitary Commissioner with the Government of India for 1897 , in RSM in $1897-98$, XXXI, p. I 20. 
the fact of the epidemic itself. By January, a little under one-half of Bombay's population had fled to a countryside which itself was ravaged by famine. It was, indeed, the grimly Malthusian balance between famine and plague that lay at the root of Bombay's survival as a city, as flight to the countryside was balanced, in the medium term, by flight from the countryside.

Plague mortality peaked in March, and receded over the spring and summer. People started drifting back to the city in the summer months, but the flow was reversed as the toll began to rise again during and after the monsoon. ${ }^{3}$ This, broadly, was the pattern for several years to come: ferocious epidemic outbreaks at the end of the year, a slackening of virulence over the spring and summer. The popular panic of the first year and a half, however, was never quite replicated, and plague gradually took its place as one of many killers that stalked a city racked by many crises.

A claim that resonated in these years tells us something a little more precise about the new social relations that may have emerged at the confluence of death, flight, and urban devastation. "The year I 897 witnessed [...] the shattering of the tie hitherto binding the employer and employed", wrote Stephen M. Edwardes, successively Factory Inspector, Census Commissioner, and Police Commissioner for Bombay, in 1902. ${ }^{4}$ This apprehension was one commonly voiced during the plague years. The nostalgic invocation of a past harmony, of course, describes no concrete reality that Bombay had ever experienced. Nevertheless, Edwardes was on to something, as was the Chief Inspector of Factories for Bombay in I 897 when he wrote of the emergence, for the first time, "of a Labour Question comparable to those of Europe".5 An epidemic crisis that was most intensely felt by Bombay's labouring poor simultaneously seems to have become the source from which unprecedented assertions of effective working-class strength flowed.

Workers in cotton mills, as one of the major social fractions within the city, and as the bedrock of its trade, played a major role in the making of this crisis, and it is their actions that I seek to elucidate in this essay. In order to do this, however, it is necessary to identify the urban social context, caught in a moment of crisis, within which the actions of workers were conceived, executed, and received their meaning. The first section of this essay, therefore, describes the popular unrest and state of anxiety that marked the first year and a half of the plague, between late i 896 and early i 898 . I move from this to a close reading of the crisis of authority that convulsed the life of Bombay's mills, as millworkers asserted and sustained new claims and

3. Abstract of the Report of the Health Officer of Bombay City for I897, in ibid., p. 228.

4. Stephen Meredyth Edwardes, The Rise of Bombay: A Retrospect (Bombay, 1902), p. 330.

5. Annual Factory Report, I897, no. FI-42 I, Home (Judicial) A, March I899, National Archives of India [hereafter, Factory Report], Bombay, I 897. 
entitlements in their daily work. This shift towards labour in the pendulum of industrial relations was grounded in larger economic and political forces in the 1890 , but reached a dramatic intensity in 1897 , one that would not be replicated for over two decades. The new bargaining power which the workers commanded flowed, paradoxically, from their mortal vulnerability. I try to explain the ways in which this precarious, temporary structure of industrial relations worked, and how it eventually produced a fresh compromise between the interests of workers and employers.

\section{PLAGUE AND ASSOCIATED PANICS, 1896-1898}

Plague began to lay claim to Bombay as early as August I 896, but it was only in winter that a genuine popular panic began to emerge. By the end of the year, there had been 2,544 plague cases reported, and I,936 deaths, of which I,27I happened in December alone. ${ }^{6}$ By the spring of I 897 Bombay was visibly a city near collapse. The contagion of plague appeared to travel the streets hand in hand with the contagion of urban breakdown. The most visible signifier of this was the devastating flight from the city. People began to escape Bombay in droves in the winter of I 896. In October, an estimated 20,000 people fled the city. In November and December, 171,500 were added to that number. By the end of January, roughly 400,000 people had fled, which amounted to a little less than one-half of the city's total population. ${ }^{7}$

The epidemic seemed to bear mortal consequences not only for the individuals who encountered it, but for the city as a whole. Shortly after the outbreak of plague, Bombay was threatened with an international trading embargo. While the British kept their ports open throughout the decades of the global pandemic, the same was not true of their trading partners. The French, for instance, intimated the possibility of riots in Marseilles, the site of Europe's last major plague outbreak in I $72 \mathrm{I}$, barring south Asian passengers from their Mediterranean ports, and issued tight controls on Indian trade, including a ban on raw hide imports. ${ }^{8}$ Such threats were seen as portents of economic death for Bombay, a future which contemporary observers, ranging from officials to visitors, held all too possible. Global pressures, then, also drove British responses to plague, formalized in the Epidemic Diseases Act of 1897 , which gave the Municipal Commissioner wide-ranging powers of regulation, without reference to a magistrate. ${ }^{9}$

6. Abstract of the Report of the Sanitary Commissioner with the Government of India for I 897 , p. I 20.

7. Abstract of the Report of the Sanitary Commissioner with the Government of India for I 896, p. 106.

8. Myron Echenberg, Plague Ports: The Global Urban Impact of Bubonic Plague, I894-190I (New York [etc.], 2007), pp. 55-56.

9. British Parliamentary Papers, I897, C.8386, p. I I. 
To colonial and municipal legislators and officials, the plague represented both a nightmare of death for Bombay, and a ground where fantasies of social control could be enacted. The hotly contested debates over the explanation of the plague, and the most efficient methods to combat it, meant that plague control had of necessity to be experimental. Between I 896 and I898, the state-authorized projects of plague control rested, successively or simultaneously, on the following measures: compulsory hospitalization and segregation of plague "suspects"; disinfection and, if necessary, destruction of homes and buildings labelled "Unfit for Human Habitation" or UHH; compulsory medical examination; forced entry into homes; projects of sanitation and conservancy. ${ }^{\circ}$

Paradoxically - but only apparently so - two dynamics intensified simultaneously in fin-de-siècle Bombay: the extension of, but also the popular attack upon, the sources of "legitimate" political authority. The measures of control outlined above were shaken, and not infrequently reversed, by fierce resistance on the streets of Bombay from the city's working classes. In October, the isolation and segregation of plague "suspects", and their removal to the hastily improvised sheds that made up the Infectious Diseases Hospital at Arthur Road in the heart of the city's mill district, triggered a violent response. ${ }^{I I}$ Millworkers, responding to rumours that the hospital was deliberately killing the sick, rioted on 29 October. ${ }^{\mathrm{I} 2}$ They threw stones at the hospital, broke into the compound, and threatened hospital employees - all during their lunch break, the riot ending as soon as the mill sirens summoned workers back to work. ${ }^{13}$ It was, however, a confrontation with spiralling consequences, as the sanitary staff of the city, reported by the Municipal Commissioner, P.C.H. Snow, to be in "almost open sympathy with the millhands", threatened to leave Bombay. ${ }^{\mathrm{I}}{ }^{\mathrm{T}}$ This threat bore terrible portents. The work of "untouchable" sanitary workers, halalkhores and bigarris, was labour that constituted the backbone of plague control. The threat of its withdrawal heralded a potential situation where "Bombay would have in a few days

Io. Ibid.; M.E. Couchman, Account of Plague Administration in the Bombay Presidency from September I 896 till May 1897 (Bombay, I 897), I, ch. I; I.J. Catanach, "Who Are Your Leaders?' Plague, The Raj and the 'Communities' in Bombay, I896-190I”, in Peter Robb (ed.), Society and Ideology: Essays in South Asian History Presented to Prof. K.A. Ballhatchet (Delhi, 1993), pp. I96-221.

I I. P.C.H. Snow, Report on the Outbreak of Bubonic Plague in Bombay, I896-97 (Bombay, I897), p.5; Couchman, Account of Plague Administration, I, ch. I; Bombay Gazette [hereafter, $B G], 8$ October 1896.

I2. BG, 8 October I 896; see David Arnold, Colonizing the Body: State Medicine and Epidemic Disease in Nineteenth-Century India (Berkeley, CA, 1993), pp. 219-220, for an account of the role of rumour in the spread of the plague panic.

13. $B G, 30$ October I896; Times of India [hereafter, TOI], 30 October I 896.

14. Snow, Report on the Outbreak of Bubonic Plague, pp. 6-7. 
become uninhabitable". is This led to an immediate reversal of plague policy, and a temporary rolling back of forcible segregation and hospitalization. ${ }^{16}$

In February, with General Gatacre's Plague Committee having taken over the administration of plague policy, and with the escalation of plague over the winter months, the colonial regime returned to an authoritarian posture. Plague Committee employees were instructed to carry out houseto-house searches, isolate victims and dwellings suspected of plague, and were given the power to mark buildings "UHH", a condemnation that came to be scrawled liberally across the walls and doors of working-class chawls (tenements) and huts. ${ }^{17}$ After a petition signed by workers across different trades failed, strike action broke out again, on 6 and 7 April I897 (the first strikes having taken place in January). In the first instance, over 3,000 casual workers, mainly cartmen employed in transporting goods to and from the docks, and coolies or casual labourers employed by the municipality, struck against the destruction of their dwellings. ${ }^{18}$ It took a large contingent of police, merchants concerned about the disruption of their business by the cartmen's withdrawal of their labour, and carting agents and contractors, to quell the strike. ${ }^{19}$ The very next day, the discontent rippled further south, and the docks stood empty, as over 8,000 dockworkers went on a day-long strike. ${ }^{20}$

A year later, in March I 898, the most explosive social confrontation of the plague years broke out. A revamped - and militarized - Plague Committee tried forcibly to hospitalize the daughter of a Muslim weaver in a densely packed working-class area known as Madanpura. ${ }^{2 \mathrm{I}} \mathrm{A}$ riot spanning much of the north of the city erupted, uniting Muslim weavers and Hindu millworkers, two fractions that had attacked each other during the communal riots of $1893 .{ }^{22}$ And true to the pattern of the previous protests, a stoppage of work - involving both workers and traders paralysed the city for a week. Small traders in grain and cloth shut their shops, bullock-cart drivers went out on strike; butchers, dockers, municipal employees and railway workers did likewise. ${ }^{23}$ This was to lead to a major reconsideration of plague policy, a scaling down of the militarized

I5. Ibid.

16. Ibid., p. 9.

17. Report from Brigade-Surgeon Lieutenant-Colonel T.S. Weir, Executive Health Officer, India Office Records [hereafter, IOR], V/27/856/7-10, Oriental and India Office Collections, British Library [hereafter, OIOC]; Snow, Report on the Outbreak of Bubonic Plague, p. 75.

I8. TOI, 2 April I 897.

19. TOI, 7 April I 897 .

20. TOI, 8 April i 897 .

21. Report by R.H. Vincent, Commissioner of Police, no. 2364/6R, to Judicial Department, Bombay, I April I 898, enclosed in Judicial Letter no. 6, 9 April I 898, IOR, L/P\&J/3/959.

22. Ibid.

23. TOI, i March I 898 . 


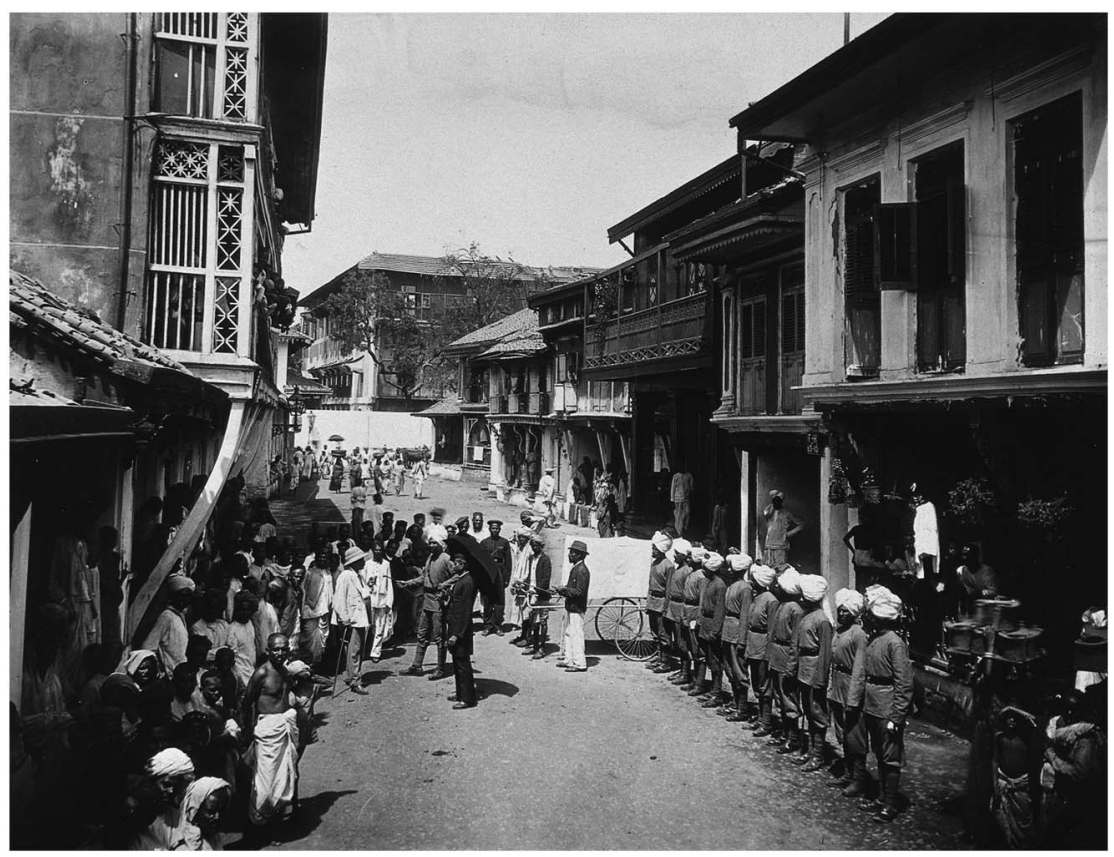

Figure I. A group of officials making a visit to a house in Bombay, suspected of holding people with plague, 1896 .

Photograph: Wellcome Library no. 37 I 3 i. Wellcome Library, London. Used with permission.

operations of inspection and segregation, and a reorganization of plague control on the basis of voluntary inoculation. So the most coercive forms of epidemic control were eventually rolled back, in large part as a response to popular rioting.

In the early years of the plague, then, two forms of contagion were dreaded by the colonial and municipal authorities in charge of Bombay. The first was the contagion of human contact, which was wrongly supposed to be the chief vector of the epidemic. The second apprehension, more abstract but equally potent, was the contagion of social disorder. The incidents I have described above seem to bear out - and were seen to bear out - the second of these threats. Popular resistance to plague measures that originated in particular localities and workspaces seemed, within moments, to escalate and infect other places and labouring locales. The effect was to draw different segments of the city's working classes into a common, active, and frequently violent opposition to plague administration, and this was a domino effect that was particularly hard to control, since it spread through streets, alleys, houses, neighbourhoods, factories and workplaces, and railways.

The plague also seems to have catalysed several kinds of connection between the different segments of the urban labour market. It is clear 
from the official records that the major threat that moments of urban unrest were seen to pose was their capacity to spill beyond their "normal" frontiers. A strike could become a riot, a riot could spill over into a strike, and the discontent of different labouring groups - millworkers, sweepers, cartmen, dockworkers, casual labourers - came to be articulated with one another in complex ways.

These articulations could be assembled through practices of solidarity: for instance, the support of untouchable sanitary workers by rioting, largely caste-Hindu millworkers in 1896 , or the unexpected solidarity between Muslim weavers and Hindu millworkers in the riot of 1898 . On the other hand, the cartmen and dockers who went on strike in I 897 complained bitterly that low-caste municipal workers were allowed to enter and disinfect their homes, but they simmered down once they were assured that their caste boundaries would not be violated. In other words, there was no generalized solidarity across occupational lines among the labouring poor, but in certain ways this might even have accentuated the threats such actions posed. The working class emerged not as an empirical unit, but in spectral form, dispersed across various locations. It emerged at the intersection of urban turbulence and state anxieties, spread across diverse work regimes and experiences, but always confronting the same enemy: arbitrary, draconian plague control.

The cessation of labour, or the threat of cessation, played a pivotal role in each of the three incidents described above (in October I896, April I 897, and March I 898). Labourers involved in municipal sanitation, local trade across the city's roads, the unloading and loading of goods at the docks, waste disposal and sweeping, and the railways, threatened to, and at various points did, go on strike. At a time when the state was seized with a sudden awareness of the centrality of their labour in the functioning of the city, such cessations of labour carried new dangers. It was this which underpinned the shifting, nervous nature of the state's plague policy between 1896 and I898: invasive advances followed by rapid backtracking, conciliation, and negotiation.

Millworkers, the largest distinct occupational group in the city, frequently partook of, and were always witnesses to, such street mobilization. They lived in clustered working-class neighbourhoods marked by complex and intricate networks of exchange and credit, dependency and solidarity, and felt the impact when the state intruded. They shared charols with other labourers, and were among the first to protest against the state's policy of "condemnation" in April I 897, in the form of a petition to the government that they drafted with other chawl residents just before the successive strikes in Colaba. The Police Commissioner, R.H. Vincent, and other contemporary observers marked them out as enthusiastic participants in the Madanpura riots of $\mathrm{I} 898$. Contemporary accounts do not, by and large, elucidate the particular ways in which millworkers were 
mobilized, or their specific actions. But there are intriguing hints: newspapers, for instance, reported a violent attack on Jacob Sassoon, one of the biggest millowners in the city, during the riot on 9 March, quite possibly originated by workers at his mills. ${ }^{24}$

In the course of the experiences of street unrest between I 896 and I 898 , then, millworkers stamped themselves indelibly upon the official gaze, as a potential source of grievance and violence. It was the crisis of 1897 that sealed the official identification of millworkers as a potential threat to the future of the city, and the stability of its economy. This threat was succinctly described by B.F. Patell, a schoolmaster in Bombay, in a poem written during the plague years:

Mill-hands, foregoing work and pay,

By thousands pour out every day;

[...]

The mills stop work for want of hands,

Mill labour now high price commands. ${ }^{25}$

It is to the convulsions of the world of mill labour, experienced most intensely through the course of 1897 , to which I now want to turn.

\section{THE CRISIS IN THE MILLS}

By the late 1890 , workers in the cotton mills numbered near 80,000 , roughly one-tenth of the city's population. The textile industry of Bombay was principally geared to the spinning of yarn for export markets in China, though the last quarter of the nineteenth century also saw a slow increase in the number of composite spinning and weaving units. Mill-workers were largely rural migrants, the largest number coming from Ratnagiri on the Konkan coast. By the end of the nineteenth century, most of northern Bombay was dominated by tall mill chimneys and congested chawls, which housed workers.

The plague crisis, as we have seen, galvanized millworkers into militant action in October I 896, but it was only in December that plague began sweeping the working-class neighbourhoods clustered in the north and east of the city, and triggered a massive exodus. Millworkers were slower to leave the city than other labourers, but the last weeks of the year, and the first weeks of the next, saw their flight attain, in the words of one of their employers, "the dimensions of a stampede". ${ }^{26}$ As a consequence, the supply of labour to the mills - at a time when the demand for Bombay yarn in China and Japan was still high - dwindled to a fraction of its

24. Ibid.

25. B.F. Patell, The Plague in Bombay (Bombay, n.d.), pp. 26-27, 32.

26. Annual Report of the Bombay Millowners' Association, I896, p. 2. 
former volume. ${ }^{27}$ To keep the mills working, millowners offered the remaining able-bodied labourers substantial concessions. The attempt to retain these concessions later on, as a matter of perceived right, by the millworkers, led to industrial conflict of an intensity that had not hitherto been seen in Bombay.

This is a theme whose absence from the bulk of research published on the labour history of Bombay is surprising. In the most important historical account of industrial relations and working-class politics that we have, by Rajnarayan Chandavarkar, a detailed description of popular politics and the plague omits all analysis of the specific disharmonies of industrial relations during the epidemic. ${ }^{28} \mathrm{He}$ is not alone in this omission.

Of late, this missing link has been skilfully restored by Prashant Kidambi, in the first major historical consideration of the theme. Kidambi takes as his point of departure an older debate among interpreters of south Asian labour and industrial relations on the question of labour scarcity in colonial Bombay. In 1965, challenging established wisdom, Morris had argued that large industrial employers experienced little difficulty procuring labour for their mills in the colonial era. ${ }^{29}$ Chandavarkar later complicated this debate by suggesting that historians turn their attention to the demand side of the equation, and consider the context of fluctuating demand for industrial labour in which the question of "labour supply" was actually situated. ${ }^{30}$ Kidambi, in contrast, argues that Chandavarkar's account of industrial relations in Bombay, in common with most others, draws most of its material from the interwar years, when indeed there was no real crisis of labour supply. The period between I 893 and I9I8, however, Kidambi demonstrates, witnessed a genuine crisis in the labour market, and unprecedented patterns of industrial strife, as relations at the workplace threatened to implode. ${ }^{3 \mathrm{I}}$

Kidambi identifies four processes at work. First, the intermittent nature of demand for cotton exports in Bombay's Far Eastern markets, underpinned by the periodic saturation of the market, the rapid growth of a cotton manufacturing industry in Japan, and the beginnings of another in China. Second, the monetary policy of the Government of British India,

27. Annual Report of the Bombay Millowners' Association, I897, p. 2.

28. Rajnarayan Chandavarkar, Imperial Power and Popular Politics: Class, Resistance and the State in India, c.1850-1950 (Cambridge, 1998).

29. Morris David Morris, The Emergence of an Industrial Labour Force in India: A Study of the Bombay Cotton Mills, I854-1947 (Berkeley, CA, I965).

30. Rajnarayan Chandavarkar, The Origins of Industrial Capitalism: Business Strategies and the Working Classes in Bombay, 1900-1940 (Cambridge, I994).

3r. Prashant Kidambi, "State, Society and Labour in Colonial Bombay, c.1893-1918", (unpublished Ph.D. dissertaton, University of Oxford, 200I), pp. 37-46. 
which removed India from the protections of the silver standard, and caused a fall in exchange rates which devalued textile exports. Third, the fiscal policy of the I 890 , which instituted tariff barriers against exports of yarn and cotton piece-goods woven in India, and thus hurt both the spinning and weaving units in Bombay. Fourth, the coupled devastations of plague and famine in western India in the late 1890 and early i 900 s. Mortality levels rose dramatically after 1896 in both the city and the countryside, which were also both rocked by flight, as peasants and landless labourers tried to escape the famine, and working-class inhabitants of Bombay fled the city with the annual recrudescence of plague. ${ }^{32}$ All this created a hitherto unprecedented shift in the pendulum of industrial relations, as Kidambi argues, away from capital and towards labour. The bargaining power of workers reached unprecedented levels between I 893 and the end of World War I, years that also saw a significant intensification of strikes and urban social conflicts of various kinds that featured the industrial working class. ${ }^{33}$

Kidambi's explanation achieves a shift in the scale of historical observation in the study of Bombay's labour relations. His account qualifies Chandavarkar's implicit framework, which, being plotted between the late nineteenth century and the I940s, is necessarily structured by the analysis of long-term shifts. Kidambi restores the importance of conjunctural analysis in the making of long-run patterns in Bombay's industrial relations. $\mathrm{He}$ identifies and delineates a new temporal frame of analysis - the period between I 893 and I9I8. This alteration of the scale of analysis helps generate new hypotheses, new orders of precedence for the intersecting historical processes of the time. I would suggest that this reversal of perspectives is best completed, and its consequences best drawn out, by focusing attention on the plague as an historical event that gives this conjuncture its consistency.

These are historical choices with fairly elaborate conceptual implications; I shall return to them at the end of this essay. For the moment, it is sufficient to register that the plague was a significant moment in "the life of labour" in more ways than one. Most obviously, it produced new sources of vulnerability and mortality, and exacerbated old ones. It also, however, produced new forms of militant self-assertion. For a while, millworkers, who were in many cases days away from death, nourished,

32. Ibid.; see also Prashant Kidambi, "Contestation and Conflict: Workers' Resistance and the 'Labour Problem' in the Bombay Cotton Mills, c.I898-1919”, in Marcel van der Linden and Prabhu Mohapatra (eds), Labour Matters: Towards Global Histories: Essays in Honour of Sabyasachi Bhattacharya (Delhi, 2009), pp. 106-I 28.

33. Kidambi, "Contestation and Conflict"; see also Sandeep Hazareesingh, The Colonial City and the Challenge of Modernity: Urban Hegemonies and Civic Contestations in Bombay, 1900-1925 (Hyderabad, 2007). 
through the persistence of their desperate demands and the force of their solidarity, a radically new form of industrial relations.

\section{THE TIE SNAPS}

Bombay's cotton mills had suffered a turbulent decade beginning in I 890 , as their main export market - China - was periodically glutted, and miniperiods of buoyancy were regularly followed by recessions in the trade in yarn and goods. The crisis of the plague years, however, was qualitatively different, and could not be reduced to a temporary market fluctuation that would correct itself through market mechanisms. The flight of labourers, beginning in the winter of 1896 , produced the tightest labour market the city had ever known, and the industry stood poised on the brink of collapse. In March I897, at the height of the crisis, the weaving sheds had been completely shut down and mills worked only 65,000 spindles out of a total of over 2 million. ${ }^{34}$ The biggest employers of labour in the city employed between one-tenth and one-third of their machinery and workers. ${ }^{35}$ Bombay's millowners were haunted by the spectre of a Bombay where their commercial interests would simply have no place, for there would be no one left to make yarn, cloth, and profits for them.

When we turn to the experiences of millworkers at this time, we find, predictably enough, desperate vulnerability. They consistently numbered I 2 per cent of the plague mortality figures. ${ }^{36}$ The credit mechanisms that ensured their subsistence collapsed, as the bania and shroff moneylenders were amongst the first to flee the city, and workers were consequently either poised on the point of death or the point of flight. Flight, even when unavoidable, offered no real answers, since famine raged in the countryside and the prospect of going home and finding neither work nor food was a real one.

The "tie" that had supposedly bound workers and employers together in previous times, snapped, in the first instance, on the streets, in the context of the crunch in the labour market. Accounts from the i 870 and I 880 s still tell us of workers sleeping by the gates of mills at early dawn in order to make it to work on time, of casual labourers thronging outside through the day, hopeful of work as badlis (substitutes). By contrast, the most resonant image of 1897 is rival jobbers scouring the streets of the mill districts, bidding up their mills' wages desperately in order to attract

34. Factory Report. At the time, spinning mills dominated the industrial landscape of Bombay, though there were already a number of composite spinning and weaving units. The early preponderance of spinning units was owing to the fact that Bombay's mills were initially geared to supply demand in Chinese yarn markets.

35. TOI, 7 January 1897.

36. Snow, Report on the Outbreak of Bubonic Plague, pp. 219-220. 
labourers at high daily rates. Consequently, workers would often leave their posts in the middle of their work and join casual labourers on the streets, to ascertain the prices offered by other mills, and walk off with the highest wage-bidder in the bazaar. ${ }^{37} \mathrm{~A}$ letter by a mill manager to the press in January I 897 speaks of "mills that actually post men at the millgate to cry out 'Ready cash paid daily in this mill; come as many as want eight annas a day". ${ }^{3}$

The practice of paying millworkers daily was an entirely new improvization, and it reversed a long-established procedure, that of keeping workers' wages in arrears for weeks, sometimes months, as security against desertion and as a form of industrial control. Assuming an arrears period of a month, a worker would traditionally be paid his November wages in January, his December wages in February, and so on, and would have to borrow copiously from moneylenders to make up the lag. An intricate interlocking of wages and credit constituted the prime mechanism of industrial control: this, rather than the mutual reciprocity contemporary observers wrote so nostalgically of, constituted the "tie" that bound workers to employers. ${ }^{39}$

Bania and shroff moneylenders, who controlled a substantial proportion of Bombay's credit, had been among the first casualties of the plague in Bombay city. "The pressing need of the poor of Bombay at the time was food", wrote A.L. Wood, Chief Inspector of Factories, "that is to say ready money wherewith to buy it; for the mass of banias had fled and petty credit had well-nigh ceased". ${ }^{\circ}$ Wage arrears, in such a situation, quite literally spelt starvation and death.

The old form of industrial control collapsed with the flight of both moneylenders and large numbers of workers from the city. Initially, most millowners tried to use the policy of wage detention to keep their workers in the city, refusing, at the beginning of I 897, to pay them their wages for November. ${ }^{4 \mathrm{I}}$ This proved unsustainable, since the panic that accompanied the progress of the plague forced workers out of the city regardless of whether they had been paid what they were owed. In the first week of January, the workers of the Indian Manufacturing Company at Ripon Road launched the first millworkers' strike of the plague years, protesting against the detention of their November wages. ${ }^{42}$ Two weeks after this, on

\section{Factory Report.}

38. TOI, I 2 January i 897.

39. For a detailed account of the emergence of the wage question in the mill politics of Bombay in the I 890 s, see Aditya Sarkar, "Regulated Labour, Unruly Workers: The Making of Industrial Relations in Late-Nineteenth Century Bombay" (unpublished Ph.D. dissertation, SOAS, University of London, 2010), ch. 5 .

40. Factory Report.

4I. TOI, 4 January I 897.

42. TOI, 8 January I 897. 
22 January, a meeting of mill jobbers drafted a petition asking employers to pay up for December. ${ }^{43}$

By this time, with the competition for labour between mills produced by the plague exodus, many employers had already begun to switch to a form of daily-wage payment. The competitive logic of this led to a significant increase in the rates of wages. In late January, the Committee of the Bombay Millowners' Association (BMOA) made ineffectual attempts to forge a consensus on wage-rates between different mills, and prescribed liberal maximum limits to day wages. In order to facilitate a return to fixed monthly wages without endangering the mills' chances of continuing to procure labour, the BMOA also fixed daily bonus rates to be paid above the fixed monthly wage, for workers not employed on day wages. ${ }^{44}$ As a mill manager, writing to the press in March, pointed out, this effectively legitimized wages that, at both daily and bonus rates, ranged between 40 and 90 per cent more than previous levels. ${ }^{45}$ Comparing levels of wage payment in I 896 and I 897 , he found that drawers' wages had jumped from Rs 9-7-0 to Rs I6-4-O, slubbers' wages from Rs I 2-I 3-0 to Rs 22-I2-O, and rovers' earnings from Rs I2-4-O to Rs $19-8-0.4^{6}$ The mills, prophesied this gentleman bitterly, "will go to the dogs". ${ }^{47}$

It was not till three months later, at the end of April I 897, that the BMOA, caught as it was between the desire of the Committee to enforce standard rates of payment and the wage competition practised by its individual members, was able officially to call a halt to the system of daily wages. ${ }^{48}$ Even at this stage, though, with impoverished millworkers streaming back into the mills, it was seen to be necessary to fix a scale of daily bonuses to offset the possibility of unrest rising from the change. In practice, it proved much more difficult to impose a return to monthly wages, and the daily wage system began to enter a terminal decline only from October onwards. ${ }^{49}$

The collapse of the wage-arrears system facilitated the corresponding collapse of many of the anchors of authority and subordination within the mills. Millowners and managers complained persistently of broken

43. TOI, 23 January I 897.

44. Circular from John Marshall, Secretary of BMOA, to Agents and Owners of Cotton Spinning and Weaving Mills in Bombay, listing scale of wages decided by committee, in Annual Report of the Bombay Millowners' Association, i896, Appendix B: The Bubonic Plague.

45. TOI, 9 March I 897 .

46. Ibid. The money denominations used are rupees, annas, and paise. In other words, Rs 9-7-0 would refer to a sum of 9 rupees 7 annas and $\circ$ paise.

47. Ibid.

48. Proceedings of Special General Meeting of the BMOA, 27 April I897, for the purpose of considering the question of resuming monthly, instead of daily, wages to millhands, in Annual Report of the Bombay Millowners' Association, I896, pp. I4I-I46.

49. Factory Report. 
machines, the confusion of functions ("a drawing room tenter is given in charge of a roving frame", exclaimed a mill manager), and the extent of waste. $^{5 \circ}$ The average outturn per head was reported to have been reduced, and labour was seen to be suffering from serious inefficiency, which caused worries about the "disrepute" Indian yarn might be saddled with in the global export trade. ${ }^{5 \mathrm{I}}$ Comments of this kind continued well into the autumn of $\mathrm{r} 897$, long after most of the millworkers who had fled Bombay at the beginning of the year had returned, and "inefficiency" could no longer be blamed on the unskilled, untrained "loafers" who had filled their places the previous winter.

The workers who returned, pushed out of the countryside by famine and attracted back to Bombay by the decline of plague and the increase in mill wages, found themselves in a completely different working environment, marked by much less industrial control and discipline. They found themselves in a strange new world, in a fluid labour market - but, for perhaps the first time, fluid on their terms. With jobbers still crying out for labour at street corners, old forms of discipline and control seemed to have cracked, and employers seemed to be having a hard time reinforcing them.

Wood, the Factory Inspector, summed up the anxieties of millowners:

And all this extra remuneration, it must not be forgotten, was paid for less work per head; less in time by late attendance and haggling at the gates of mornings and by early stoppage for payment of evenings; less in quantity through slackness of discipline in all departments and, in those commonly paid by piece, not only through the loss of that incitement but through the failure of the attempt to impose even a minimum daily task. ${ }^{52}$

Jamshedji N. Tata expressed the matter with even more felicity: for him, daily wages "had at the present moment placed the employers of labour in the unenviable position of employees". 53

If these words express an anxiety about declining standards of industrial efficiency, they communicate an equal worry about the forced loosening of authority. Many of the material ties that bound workers to their work had now disappeared. To quote the Factory Inspector again:

A man would stand before a mill-gate in the morning, knowing little or nothing of the work that went on inside, but sure of a welcome and of half a rupee if he stayed there till evening. Next day he would walk the streets spending his half rupee, and would hear that another mill was going to pay nine annas. On the third morning he and his likes would beset the gates of the second mill, and the first would run so many spindles shorter. ${ }^{54}$

50. TOI, I 2 January I 897 .

5. $B G, 30$ April I 897 .

52. Factory Report.

53. TOI, Iо May 1897.

54. Factory Report. 
Dismissals, to which millowners had easy recourse in normal times, must have been harder to effect or even to contemplate at a time when any labour available would have seemed evanescent.

If hitherto reliable modes of coercion vanished, with employers as desperate for labour as they were, so did the structures of incentive that sustained the long hours traditionally worked in Bombay's mills. Piecework, which kept workers working longer and often overtime in search of a higher wage, had by now largely been replaced by fixed day wages or bonuses, and could no longer be an instrument of industrial control.55

Workers thus had more control over their work time, and instead of beginning their work at sunrise as they had for decades, now found it possible to stay away from the mill till 7 or 8 in the morning. ${ }^{56}$ The withholding of wages in arrears had, for the moment, come to an end. It was possible for a worker to walk from street to street freely looking for an employer who would give him a high wage; it was no longer necessary to be tied down to the routines and petty frustrations of a fixed job that had to be eked out day by day, and work requirements, in a situation where simply keeping the machinery running was the stated priority of millowners, were slack.

Street-corner bidding for labour, increased wages paid at the end of each day, bonuses, and intimations of industrial sloth and insubordination: these practices and apprehensions were knitted into a common framework of working-class bargaining power in the early months of the plague. Such inversions of the normal pattern of industrial relations were bound to provoke strong responses. In early February, A.L. Whittell, engineer and manager of the Union Mills in Parel, wrote bitterly of the way workers "decamped" to other mills which paid higher daily wages, the moment they had received their arrears. Mills, despite paying daily wages and offering free rice, were short of men, "and the majority of those that come are schemers and doggers, ruining the machinery and turning out bad work. They will work for a day or two, and then hearing of another mill offering an anna or two more daily, will be off there." 57 The regular monthly workers, observed Whittell, took advantage of this situation, and despite the blandishments and sops held out by their old masters - free rice, dal, etc. - regularly walked off to other mills without a word of notice. ${ }^{58} \mathrm{He}$ concluded:

My experience of seven and a half years has taught me [...] that, taken in the majority, he [the millworker] is a fraud, and that the only way to manage him $[\ldots]$ is in the first place to owe him a substantial amount of his wages, and in the 
second place to "rule" him with a rod of iron, to be firm, and very sparing, with kindness where due. 59

Rumblings of this sort had little purchase in February, with the mills still working at less than half their capacity, and labour a scarce commodity. But as the first wave of plague passed, and workers began to flock back to the city in April, complaints in this vein began to gain in urgency and force. The Millowners' Association began to take a harder line on daily payments. Hesitantly and half-heartedly, with very little coordination among themselves, some millowners began attempts to roll back day wages and restore the older system of monthly payments.

This sparked a series of confrontations between employers and workers. If the flight of workers, and the expansion of the bargaining power and entitlements of those who remained, had marked the winter and spring of I 897 , the summer was characterized by a series of strikes, big and small, in defence of these now threatened entitlements. At the beginning of June, the millowners made their first serious attempt collectively to confront the crisis of authority with which they were faced, and announced a return to monthly wages in a number of factories in Mazagaon, Byculla, Kamathipura, Tarwadi, and New Nagpada in the E Division of the city, and in Mahim, Worli, and Parel, in the $F$ and $G$ divisions, further north. ${ }^{60}$ They were instantly faced with a strike of impressive proportions. Workers in over thirty mills came out on the streets and assembled in front of their workplaces early on the morning of I June, and continued to withhold their labour, obdurately, for over a week. ${ }^{6 \mathrm{I}}$

In contrast to the images of riot and disorder that pervaded contemporary accounts of collective millworkers' action, and which had been given some force by the riot in October, this was a disciplined and peaceful strike, but the message was clear: the workers would not countenance a return to the earlier system of monthly wages with a month's arrears as deposit. ${ }^{62}$ Shareholders and millowners, writing to the press, urged that the time had come for decisive action against the blackmail workers were subjecting their employers to: "Who are to be the masters of the situation, the work-people or the mill-agents?", wrote an irate shareholder. "The work-people had it all their own way for some months, and are not likely to give way at once." ${ }^{\prime 3}$ He suggested an escalation of hostilities - a withdrawal of the bonus as well as the daily payments to which workers had become accustomed.

59. Ibid.

60. TOI, 2 June I 897. The places mentioned made up the heart of Bombay's mill district, concentrated in the north of the city.

6r. TOI, 3 June, 4 June I 897.

62. Ibid.

63. TOI, 4 June I 897 . 
The strike lasted nearly ten days, waxing and waning as some of the mill workforces capitulated and new ones joined the ranks of the protesters. An uneasy compromise was reached after 9 June, whereby the workers from several mills tacitly conceded a return to monthly wages, but claimed, as their pound of flesh, all their previous arrears, and enhanced rates of bonus. ${ }^{6}{ }^{4}$ The strikes, in the Factory Inspector's words, "were summarily terminated by the arrival from the Agents' offices of the silver earned half a year before", 65 and, in addition, daily advances equivalent to the bonus were given to workers, which constituted, in effect, a disguised form of daily wages. ${ }^{66}$ The millowners' offensive in June, then, produced less than satisfactory results.

At the beginning of July, fresh crises broke out, dispersed across several mills in central and north Bombay. Workers in some factories protested against attempts to discontinue their daily advances; in others, they struck against the reduction of their bonuses. The prime agents in many of the strikes in July, however, were Muslim weavers (known as julabas), who, while better-paid than most of their counterparts in other mill departments, had often been laid off through the year, as millowners chose to close down temporarily their weaving sheds and concentrate on spinning, the demand for yarn outstripping that for woven goods. With the cotton export trade improving over the summer, the weavers came back to work, but were denied the bonuses and advances granted other workers. Violent strikes broke out in several mills, involving clashes between weavers and strike-breakers hired by their employers. The millowners climbed down again, and the weavers got their bonuses. ${ }^{67}$

Strikes continued, with diminishing frequency, till September. The main points of contention continued to be attempts by millowners to withdraw daily wages and bonuses, though in one instance, in August, there was a small but violent strike against the withdrawal of grain compensation as well. ${ }^{68}$ There are teasing suggestions here: if workers could demand grain compensation from their employers by right, do we have in this the intimations of new moral economies, born at the point of a crisis?

By October, millowners were effectively masters of the situation again, as the city's workforce finally returned to its normal levels and it became feasible to restore some of the old practices of industrial control. However, those who commented on the mills noticed a new spirit of sustained tension. "There remains in the chawls of Byculla and Parel", observed Wood, "a spirit of independence, not to say unrest, which was

64. Factory Report.

65. Ibid.

66. Ibid.

67. Factory Report; TOI, July I 897.

68. TOI, 24 August I897. 
unknown before. The immemorial trades-unionism of caste and kinship and country has for the first time asserted itself, and not without a measure of success: it will make itself felt again should need arise."69

\section{RECONSTRUCTING INDUSTRIAL RELATIONS}

This strange yoking of death and power, which inspired the successful defence by millworkers of their new rights, lasted till the summer of I 897, when it began to crack under the pressures of the restabilization of the city's labour force, a slow but real process. The conclusion of this process, not surprisingly, was the reconstitution of the power of millowners within the industry. However, the effects of the plague were serious enough to make it clear that the forms of employer power would themselves have to be re-imagined. They could not be precisely the same as they had been before. In this section, I offer a brief consideration of the two major streams of thought that emerged among millowners in their attempts, in I 897, to reconceptualize the ordering of industrial relations.

The first of these schemes was a strategy devised by Jamshedji Tata, who was fast emerging, by the late I 890 s, as the prime organic intellectual among Bombay's industrialists. As early as I 888, Tata had written to the Government of Bombay and the Millowners' Association, urging them to facilitate the importation of landless agrarian labourers from the northwest provinces to work in Bombay's mills, on the grounds that labour was becoming more expensive in the city, and workers from the north, accustomed to lower standards of living, would work for lower wages. He was turned down unequivocally on that occasion by the Government of Bombay, which held that assisting privately owned mills to procure labour, through what would effectively be a process of impressment, was not part of its remit. ${ }^{70}$ The Millowners' Association also felt that this was a policy which imposed artificial patterns upon the natural relations of the supply and demand of labour, which would adjust to produce the optimal results, and the optimal labour force. Undeterred, Tata repeated his plea to the Millowners' Association in 1892 , and was turned down again, on the same grounds. ${ }^{71}$

The plague provided Tata with the perfect opportunity to put forward his favourite project forcefully. In a series of letters and statements addressed to the Committee of the Millowners' Association in I897, he argued that the relative cheapness of northern labour, especially at a time when famine was ravaging the agrarian population in the north, would

69. Factory Report.

70. Abstracts of Proceedings, General Department, Bombay Government (Misc), is October I $888, \mathrm{IOR} / \mathrm{P} / 3336$, OIOC.

7I. Annual Report of the Bombay Millowners' Association, I892. 
provide a much-needed antidote to the indiscipline and inefficiency of the Konkani, who would "wake up to a sense of his own worthlessness and incompetency, and return fair value for the wages paid to him". ${ }^{72}$ Saddled with an undue sense of his own importance, and his temporary position as "master of the situation owing to his enjoying a monopoly", the Konkani labourer was likely to "hamper the legitimate growth of the industry in Bombay". ${ }^{73}$ The labourer from upper India, on the other hand, was ideally suited to mill work in Bombay, since, owing to his landlessness, he had no material ties to cultivation, which always constituted an alternate pole of attraction for the Bombay labourer. The northern labourer would be transported along with his family, and would, unlike his Konkani counterpart, entirely lose his ties with the land, and become dependent upon the mills for his livelihood. ${ }^{74}$

At a time when the Konkani workers castigated by Tata were undermining the bases upon which authority in Bombay's textile mills functioned, this was clearly an idea whose time had come. In what appears to have been a cleverly timed piece of public relations strategy, Tata gave a press interview in May where he spoke disparagingly of the workers he currently employed, and the "dilatory and easy-going manner in which these men worked", and publicized his strategy. ${ }^{75}$ The strike in June I 897 spurred the BMOA into action: Tata's scheme, in the light of the current labour unrest in the city, was applauded as a potential solution to the dangerous deadlock in which millowners found themselves, and a way of containing the cycle of escalating strikes and militant demands. On the day the strike broke out, immediately after the mills had reverted to monthly payments, the BMOA unanimously passed a resolution agreeing to facilitate the importation of labour from the north. ${ }^{76}$

The subsequent fortunes of the scheme, however, belied the hope with which it was launched. An agent, a Mr Moolla, was appointed with a budget of Rs 3,000 to travel to Nagpur, Kanpur, and other parts of the central and north-western provinces to procure labour. He met, however, with fairly humiliating refusals. The wages offered by the BMOA (which were considerably below what the Bombay millworkers were being paid

72. Jamshedji N. Tata, "Imported Labour for the Bombay Mills", 26 May i 897, enclosed in Annual Report of the Bombay Millowners' Association, I896, p. I56. The workers employed in Bombay's textile mills were mainly drawn from the Konkan coast of western India, and in particular from the district of Ratnagiri: hence the term Konkani which Tata used as a shorthand to describe mill-workers.

73. Ibid., p. I 57 .

74. Letter from Tata \& Sons to John Marshall, Secretary, Millowners' Association, Bombay, I I May I897, enclosed in Annual Report of the Bombay Millowners' Association, I896, pp. I $58-160$.

75. TOI, Iо May I 897.

76. TOI, 3 June 1897 . 
in the summer of I 897) were rejected by most of the people he approached. He found only i 44 people willing to accept the rates offered by the BMOA. For the mills which managed to procure northern labour, the experience proved unsavoury, "as the men had, in many cases, refused to work at the wages laid down in the agreement and left their employment" ${ }^{77}$ By the end of I897, Tata's vision, an ambitious drive to reconstitute the labour market utterly as well as a geographically extended strategy of strike-breaking, was finally given up.

The other scheme imagined by millowners responded in a different way to the challenges posed by the labour situation in Bombay, but nonetheless shared Tata's premises at some fundamental levels. This involved Nowroji Nusserwanji Wadia, who cut a slightly unusual figure among millowners in this period, and briefly became one of the more outspoken critics of the negligence of employers. He was one of the richest millowners in the city, and came from a family which had made fortunes in shipping, trade, and finance. His family, in common with the Petits, the Sassoons, and some other large commercial family firms of the time, had major investments in philanthropic projects in Bombay. ${ }^{78}$

During the strikes of the summer, he was one of the few employers who supported the continuation of bonuses for workers, at a time when there were many who were angry enough to call for the cessation of all concessions to employees. ${ }^{79}$ Wadia consistently foregrounded an ethic of reciprocity and care in his public pronouncements. His main intervention, which dovetailed with the preoccupations of the Bombay Government, was an argument for the provision of cheap housing for millworkers. Each mill, argued Wadia, should house its own workers. ${ }^{8 \circ}$

The alternative he offered, then, was a systematic paternalism, which had some material foundation in the practices of some mills, such as the setting up of shops to provide grain to workers on mill premises, and the construction of makeshift dwellings on mill land for them. ${ }^{8 \mathrm{r}}$ As one of the bigger landlords in the city, Wadia had both the will and the means to launch such housing schemes. The intention, according to the Factory Inspector in a maudlin moment, was "to bind employer and employed together by a more humane tie than mere rupees [...]. Perhaps this is a dream, but it is a good dream, and I may therefore be pardoned for indulging in it." ${ }^{\prime 2}$

77. Annual Report of the Bombay Millowners' Association, I897, pp. 5-6.

78. Ashok V. Desai, "The Origins of Parsi Enterprise”, in Rajat K. Ray (ed.), Entrepreneurship and Industry in India, I800-1947 (Oxford, I992), pp. 99-108.

79. Proceedings of Annual General Meeting of the Bombay Millowners' Association [hereafter, Proceedings i 897 ], 6 July i 897.

80. Factory Report.

81. Proceedings i 897; Factory Report.

82. Proceedings i 897 . 
Wadia's scheme, as it turned out, proved to be one of the foundations of the Bombay City Improvement Trust, a collaboration between state and private business geared towards the radical reshaping of city space, and rehousing of the urban poor. Wadia's ideas for the reconstitution of capitalist authority pointed in a direction that was different from Tata's, and reflected the emergence, for the first time, of a welfarist thrust in the strategies of control formulated by private business. Factory Inspector Wood noted that the plan, if accomplished,

[...] should lead to the supplying to the workpeople of the necessaries of life not excepting that all-pervading necessary credit - and even of some of its comforts; to the substitution of competition in the provision of good dwellingrooms, and of facilities for obtaining necessaries and comforts, for competition in mere money-wages; and to the creation of clans of men who will hold to the same mill from father to son, as they hold to their forefather's fields. ${ }^{{ }_{3}}$

In other words, the purpose of the plan was to institute a form of employer control that was founded on welfare, on the necessity of taking steps to ensure the reproduction of the labour force.

Tata and Wadia's strategies may have been conceived with slightly different ends in mind: the former explicitly addressed the question of labour control, whereas the latter claimed a more principled and meliorist basis. But they pointed in the same direction. In the first place, they contended with a new world of industrial relations where the practices of employers and employed bore the stark imprint of a war of position, where victories rested on the capability to formulate new, sometimes radical, strategies. In the second place, employers were directly affected by the form that workers' vulnerabilities now took. The disappearance of credit mechanisms that had sustained workers' daily needs, after the flight of a large portion of the city's moneylenders, produced a situation where a more directly negotiated relationship between capitalist and worker seemed unavoidable. For the workers, daily wages received in cash were the solution. Tata and Wadia's visions were predicated on the same need: employers needed to find a way to bind labour to their mills, and subsidized immigration and housing were momentarily plausible solutions. The social reproduction of the workforce, both Wadia and Tata realized, could not, at this moment of crisis, be left to itself. In a sense, the workers' demand for grain compensation in August I897, mentioned above, complemented such initiatives. Both at the level of working-class demands and at the level of employers' strategies, the question of social reproduction seems to have acquired a new urgency.

The moment, however, passed. Once the plague crisis had lost its immediacy, real-estate speculation, and the interests of the propertied 
classes in general, substantially reworked the structure of housing welfare suggested by Wadia. The Bombay Improvement Trust was a project undertaken jointly by the state and private commercial and landowning interests in Bombay, in that sense a classic broad alliance of the city's ruling classes. It fell prey soon enough to the pressures of cost-cutting minimalism, which generated unsatisfactory and often delayed housing for workers in the vicinity of their workplaces. Welfarist impulses like Wadia's were twisted into more parsimonious forms in the actual work executed by the Improvement Trust (and, to a significant extent, by its successor, the Bombay Development Department, set up in 1920). ${ }^{84}$ It was difficult, until major reforms in workers' housing enacted by the Congress ministry of I937-1939, to persuade tenants to settle in their new tenements, which lacked adequate water facilities, sanitation, and living space. ${ }^{85}$ The expropriation of the city's poor from their homes and neighbourhoods ran far ahead of their rehousing and resettlement, thus establishing and extending a pattern in Bombay's growth that lasts to this day.

\section{CONSEQUENCES AND CONCLUSIONS}

Through the I 870 s and I880s, millworkers had appeared in the discourses of employers and state in various guises, most of which reduced them to passive beneficiaries/victims of industrialization, grateful recipients of protection from a benevolent state or charity from kind employers. In the twentieth century, by sharp contrast, they were to appear alternately as riotous mobs or, later, as militant class warriors corrupted by Bolshevism. The I 890 s provide a semantic as well as a temporal bridge, and I would suggest that the plague years constitute the critical bridging period, when the working classes emerged as a persistent force of disruption, their demands and collective mobilizations imposing a heavy burden upon the coercive and regulatory apparatuses of state and employer alike.

It would be tempting, but far too simple, to conceptualize the labour unrest that hit the mills between 1896 and I 898 through the optic of an all-pervasive chaos, as a sort of historical aberration. Superficially, the evidence sometimes seems to point strongly in that direction: workers milled about on the streets at a time when their employers could not work out how to keep them working; they rioted and went on strike; mills closed or worked with half their workforce, and the industrial base of the city was nearly shattered. It was, by any standards, a time of convulsion and disorganization.

84. See Prashant Kidambi, The Making of an Indian Metropolis (Aldershot, 2007), pp. 71-i I 5 , for an account of the operations of the Bombay Improvement Trust.

85. I am grateful to Vanessa Caru for sharing her work on Bombay working-class housing with me. 
If this is the whole story, then we are left with a neat, if absorbing, narrative, fully decipherable within the digits of orthodox economic history. Plague depopulated the city, workers fled in droves, and those that remained gained ascendancy in industrial relations momentarily, as a consequence of their relative scarcity in the labour market. However, as they returned through the summer, history began to readjust itself to more "normal" patterns of industrial relations, and the plague crisis remained just that, a crisis, a ripple upon the surface of an unfolding narrative of industrial growth and prosperity. Morris David Morris offers a classic formulation of this in The Cambridge Economic History of India: wages, he writes, suffered temporary fluctuations, but the "unstabilizing effects" of this were "worked out" by mid-1 $898 .{ }^{86}$ However, something else was happening as well: even as old patterns of industrial relations were torn apart, they were being reconstituted, in complex and contested ways.

The documents of the time confront us with four dominant and vivid images of Bombay's millworkers in 1896-1897. First, the spectacle of terrorized families of millworkers fleeing the island as the plague advanced steadily and inexorably upon working-class neighbourhoods, emptying mills of their workforces. These workers were, soon enough, caught between the Scylla of plague and the Charybdis of famine in the countryside. The later influx into the city from the villages paralleled, though perhaps did not equal in its intensity, the panic-driven flight at the turn of the year. Second, the image of rioting mobs, armed with sticks and stones, engaged in pitched battles with the police on the streets of Bombay as they attacked hospitals and policemen, angered by the segregation measures called into being by the plague. Third, an army of "loafers", irregular or substitute workers, and casual labourers thrown into a situation where mill jobbers thronged at street corners offering them work, high wages, and benefits. Fourth, and finally, a working class galvanized into the defence and extension of its wage entitlements by the bargaining power gained from the labour shortage induced by the plague exodus, in the form of massive and successful collective strike action.

If we gather these images up together into a single abstraction, and organize them under the sign of a single urban proletariat, we commit an act of violence upon the actual nature of the working class of the time, which was diverse, segmented and very far from any version of a "classfor-itself" (at least, if the term is understood in a narrow sense). But this act of violence is also a necessary one, for it makes more comprehensible for us the ways in which the state and capitalist employers conceived of

86. Morris D. Morris, "The Growth of Large-Scale Industry to 1947", in Dharma Kumar and Meghnad Desai (eds), The Cambridge Economic History of India, II: c.1757-c.1970 (Cambridge, 1983), p. 577. 
the labour force, and also the ways in which orthodox economic history reconstructs this period. ${ }^{87}$

A working class was driven out of the city by the peril of plague and imminent death, and a textile industry staggered under the burden of labour shortage. We have employers offering major concessions, raising wages, dispensing with the old practice of keeping arrears in hand, and generally doing whatever they could to supply their mills with enough labour to keep production running. We have labour in greater demand than ever before, able to command its terms. We have a militant and sometimes riotous new working class stamping its presence upon the city, resisting attempts to segregate families of workers to avert the plague, and threatening officials of the state with violence. We have this working class holding on tenaciously to the benefits wrested from their employers through the conjuncture of labour shortage and militant strike action, and the growth of a slow movement among millowners to roll back these benefits as the danger of plague recedes. We have the waning of the brief labour movement, and eventually a re-stabilization of the sovereignty of employers, though the latter have to move considerably from their initial ground to regain and sustain their hegemony.

It is also necessary to begin with this level of abstraction because it confronts us with an important historical paradox. No working class could have been more vulnerable, less geared, less historically "ready" for the strength of the claims it was making upon capital and the state, than the Bombay textile workers of the plague period. The benefits won were, literally, snatched at a point of mortal despair. But the concessions they wrested from their employers, and the patterns and resolutions of their confrontations, remind us of forms and outcomes of industrial bargaining in working-class movements that were far more "mature".

This is where it is necessary to break the abstractions down, and disaggregate. Reading the documents of this time, one is persistently reminded that the different images described above actually represent different working classes. The workers who attacked the hospital on Arthur Road in October I896, well before the plague and its repercussions had made themselves felt within their neighbourhoods, were a relatively "settled" class - not necessarily assured in their occupations, but nevertheless constituting a more or less stable labour force, made up of a combination of regular, semi-permanent, and casual workers whose admixture was to some extent predictable. Despite the fluctuations of trade and of the China market that had beset employers in the I89os, the patterns of migration, settlement in Bombay, and employment in the

87. And, perhaps, the ways in which orthodox Marxists would have understood these events if they had analysed them at length. 
cotton industry had by then stabilized into certain traditions of life, work, law, and labour relations. By the turn of the 1890 , sections of millworkers were beginning to organize themselves more often and more militantly as a collectivity - though one always undercut by divisions of skill, caste, region and gender.

By early i 897 , the solidarities and connections that founded this kind of protest had been cracked wide open, and there was, strictly speaking, no permanent workforce left in the city. The workforce had dwindled to one-fifth of its original size. The image of jobbers hawking their services on the streets, openly bidding for labour at street corners, tells us that employers and intermediaries had been powerfully affected by the mass flight of millhands. Irregular workers, casual labourers, people who had never performed mill work before, people drifting between employment in mills and other occupations, the vast numbers whom the censuses tabulated as "general labour" - these constituted a new workforce for the mills. What this demonstrates, above all, is the fluidity of occupation and the arbitrariness of stable occupational categories in a labour market as volatile as Bombay. It reminds us that workers, even those identified officially as "millhands", could actually pass through the portals of several labouring existences in the course of a lifetime, and that mill-work could be a moment, rather than a terminus, in a life of labour. One can sense, intuitively, the intensified interpenetration of different labouring worlds, and different categories of "worker" in this time.

Accounts of this time usually agree that millowners went to great lengths to persuade their workforces to stay, to retain their labour force they set up accommodation near the mills, they established free and subsidized supplies of grain and cloth on the mill premises, they raised wages, they agreed to pay wages daily, they paid bonuses to their workers. But what is less frequently remarked is that millowners and jobbers were not so much "retaining" an old labour force with all its characteristics, as producing a new one. The "loafers and idlers" who suddenly found regular employment in the mills, the badli workers who found themselves elevated to the status of regular employees, the turbulent "troublemakers" who now both serviced and undermined the needs of the industry - all these formed a new constellation of industrial labourers, distinct as a collective from their predecessors. When regular millworkers came back to their city after the initial plague panic had abated, they found themselves shoulder to shoulder, in a still tight labour market, with new colleagues, in a situation of unprecedented economic strength.

What was the character of these industrial proletarians? There are no systematic descriptions available, but certain things are obvious. First of all, they were defined by the constant, unremitting presence of disease and potential death. Millhands regularly filled hospitals, funeral ghats, and cemeteries. Their needs and their expectations were thus immediate and 
urgent - not long-term stability of employment, not better working conditions, but the security of money in hand at the end of the day. Thus, the strikes initially launched by the millworkers focused on the replacement of monthly wages with a fortnight's arrears in hand - the custom of most Bombay mills - with wages received in hand at the end of the day.

Second, flowing from this, here was a mill proletariat clearly defined by a new industrial militancy. The language of factory inspectors, census commissioners, and millowners of the time was scared, nostalgic, regretful: "the age-old tie binding employer and employed has been snapped", "a labour question comparable to Europe has emerged", "the men know their strength". But these "men" knew their strength at a moment of unparalleled weakness, and of radical vulnerability.

The forms that the millworkers' actions took in this period furnish us with another possible optic. What precisely were factory labourers doing in the most dramatic months of I897? The answer is that they were demanding reconstituted terms of employment, and sustaining them through powerful demonstrations of collective force. Concessions that were from their masters' point of view tactical gambits to keep them working, or acts of charity to save them from utter destitution and despair, had become, for workers, rights to be defended at all costs. Charity was translated into right. Through I 897, workers made successful demands that threatened the structure of industrial relations that had persisted through the preceding decades. Despite admonitions from the Millowners' Association, the majority of individual employers saw surrender to these demands as the only means that could secure labour for them.

The point is that in the months under discussion, the relationship between employer and employed achieved its own micro-historical stability, achieved through the setting of new standards and practices of wage-payment. The daily wage and the bonus were, in their initial form, concessions born of pragmatic choices made by millowners. But once granted, they became claims that structured, for almost a year, the forms of industrial relations in the city. This was not pure chaos born of a desperate situation. To reverse this and restabilize an older structure of employer control required protracted conflict and the defeat of militant strike action. All this makes up a slice of historical time when a particular form of regulation was achieved, one which we might describe as regulation from below - sustained by the conjoined threats of disease, death, workers' flight, and industrial protest. It was a time of militant, far from unorganized, industrial conflict, something that could no longer be viewed as an "instinctual" response to industrial conditions that would disappear as the industry gained a firmer footing.

I 897, then, was not simply a year of industrial chaos, but a year when a new, contingent and fleeting structure of industrial relations was devised, through the capitulations of millowners and the assertions of workers. 
The temporary gains made by workers at the height of the plague crisis, and the strength of their agitations, suggest a far more classically "mature" working class, the kind that is supposed to grow into a corporate, unionized, stable identity with the expansion and development of industrial capitalism. The strangeness of this historical moment, thus lies in the fact that such gains were made not at a moment of strength, but of constitutive, defining weakness and vulnerability, both for capitalists and for workers. Instead of the (partly) virtuous cycle of industrial growth and working-class ascendancy that has been seen to characterize the "normal" trajectory of industrial relations, this structure of workers' strength was sustained by a backward spiral, which threatened both the cotton industry and its workers. These were workers who often enough did not know if they were likely still to be alive in the near future. What they could be assured of was a daily wage.

What also emerged during these years was a closer relationship between state and capital, as labour came to acquire the status of a major political problem for both. The scale of the millworkers' assertion in $1896-1898$ was unprecedented in the prior history of the city's mills, and the increasing demographic preponderance of millworkers within the city's population was beginning to crystallize in more active, "agentive" forms. In response to this, common or compatible structures of control needed to be devised by both the state, to ensure civic stability and the reproduction of the power relations that sustained the city, and by employers, to reinstitute their authority over an increasingly fractious workforce.

If the attempt to overhaul the structure of working-class housing was an agenda executed by an alliance of the state, private business, and landowning interests, the problem of civic order was faced most directly by the state. The reorganization of the city police, and the consequent intensification of coercive police controls, was a marked feature of early twentieth-century Bombay. Stephen M. Edwardes's attempts, as Police Commissioner, to control the Muharram processions in the city more tightly bore traces of an anxiety carried over from the i $890 s$. This concerned the opacity of the plebeian and proletarian fractions of the Muslim community to state scrutiny, and the perceived potential for riot and rebellion that the Muslims, julaha weavers predominantly, had displayed in 1893 and equally strikingly in $1897 .^{88}$

In late I896, the Government of India belatedly responded to the worries expressed by factory inspectors to the Royal Commission on Labour for Britain and the Empire, whose representatives had visited India in 1892 , and asked for information on wage practices from the 1923); Kidambi, The Making of an Industrial Metropolis, pp. I I5-I57. 
Bombay Government. ${ }^{89}$ The convulsions of the plague crisis seem to have stopped whatever correspondence there was on this issue, and a comprehensive reply only arrived in February i 898, in the form of a letter from R.M. Kennedy, the Collector of Customs and Land Revenue for Bombay, and an appended report by Wood.

The mill industry, wrote Kennedy, "is now passing through a convulsion in which the mill owners have by no means the most advantageous position, and it appears to me wisest to see how the relations between employer and employed will stand at the conclusion before interfering with circumstances". ${ }^{\circ}$ Wood was less circumspect:

The masters have for many years professed to be in combination, but this is now proved to have been a fair-weather combination. No doubt they will try - and have tried - to secure better cohesion, but their elements are various and discordant. The men are a homogeneous mass who have now for the first time combined - by accident, it is true, but with conspicuous success. What they have done by accident they will know how to do by design. In my bumble opinion, the Bombay mill-band can now look after himself. $9^{\mathrm{I}}$

\section{THE PLAGUE AS HISTORICAL EVENT}

Some conceptual considerations are necessary in order to round off this essay. To begin with, let me recall Prashant Kidambi's important contribution, which delineates the conjuncture of I893-I9I8 as a sort of temporal bloc which throws fresh light upon the long-term history of Bombay's labour relations..$^{92}$ The movement is one from "structure" to "conjuncture", reversing, as it were, Fernand Braudel's prescriptions about the hierarchy of structure (or, more precisely, longue durée), conjuncture and event. ${ }^{93}$ Kidambi's narrowing of temporal focus helps to isolate a specific and unusual period in Bombay's social history where long-run structures and immediate contingencies can be shown to overlap.

The reference to Braudel is not accidental. The specific claims about the hierarchy of temporal scales he famously put forth in The Mediterranean have seemingly been reversed by micro-history and subsequent developments in historical thought. The passage of the Annales school's pre-eminence in historical studies, and, at the level of philosophical correlates, the disappearance

89. No. I 576, Calcutta, I7 December i 896, Home Dept (Judl.), L.M. Thornton, Deputy Secy. to GOI, to Government of Bombay, in General Department, Bombay Government [hereafter, GD], no. 37, I 898, Maharashtra State Archives [hereafter, MSA].

90. No. FI-77, in GD, no. 37, 4 February I898, MSA.

91. No. FI-69, in GD, no. 37, i February i 898, MSA (italics mine).

92. Kidambi, "State, Society and Labour in Colonial Bombay".

93. Fernand Braudel, The Mediterranean and the Mediterranean World in the Age of Philip II (London 1995), I, pp. 20-2I. 
of structuralism as a dominant theoretical paradigm, might seem to render Braudelian questions out of date. Yet, the relationship between pieces of historical analysis and their relevant temporal frames, however implicit in the actual work of historians, remains a crucial one. In the specific context of this article, it might be remarked that histories of Bombay invariably look rather different with the alteration of the temporal scale of research, and this is not mere optical illusion. The point is that the precise relations between different temporal scales remain unresolved, and it could be ventured that each historical analysis opens up this question anew. In other words, the relations of hierarchy between structure, conjuncture, and event remain crucial in historical analysis, but usually at an implicit level. In the pages which follow, I will try to make some of the issues at stake a little more explicit.

Braudel famously criticized an older generation of historians' concern with the "flotsam" of historical events, which he saw as ephemeral and superficial, producing illusory excitements which dissembled the vast structures underlying social life, structures that only change slowly and are impervious to events and individuals. In the context of the conventional "event-oriented" histories he had encountered, anchored to the decisions of monarchs and political leaders, his disparagement was fully justified. However, in strictly conceptual terms - and especially when considering histories plotted on a less grand, less civilizational scale than that mapped by Braudel - it may well be necessary to reconsider the relations between structure, conjuncture, and event in ways that reverse his hierarchies and priorities.

My purpose, in a sense, is to complete this reverse-Braudelian movement by restoring to the event (here the plague pandemic) its full historical efficiency. It is of course necessary to understand the large structures of class, geography, ecology, and economy which gave form to the plague's social effects, in order to demystify the apparent suddenness with which the epidemic burst upon Bombay. However, I would like to argue, perhaps controversially, that such demystification, stretched beyond a point, can actually produce a reverse mystification, by rendering the new and traumatic intrusions of a social crisis in overly familiar terms. The "surface" strangeness of the plague cannot be exhausted or cut down to size by carefully historicizing its conditions of emergence. Different scales of historical temporality are simultaneously at work in historical processes. It is important not to conflate these scales with one another. In other words, reducing the plague to its "conditions of emergence" whether understood in structural or conjunctural terms - is to refuse to understand what constitutes its "event-ness". Such a reduction would erase precisely the force that gives it the quality of an event which exceeds its conditions. It is this excess which makes it possible, up to a point, to isolate it as an object of historical enquiry.

These reflections are marked by Alain Badiou's understanding of the event as that which suspends the "normal" order of "Being", by releasing 
a new "historical sequence" which only makes narrative sense in the light of this rupture. ${ }^{94}$ Thus, for instance, an authentic political revolution is not measured by the scale of its immediate break with circumstances this break may well be, and in fact usually has to be, extremely limited. Its "event-ness" consists, rather, in its introduction of a new sequence of actions, decisions, desires, and dreams that is beterogeneous to the situation from which it is born. An event, in this sense, marks the birth of the new, but in ways that are rarely immediately transparent. Slavoj Žižek has extended Badiou's considerations by clarifying their apparent temporal paradox: a historical event only becomes so retroactively, in the light of the sequence it initiates. ${ }^{95}$ Historical temporality, therefore, is marked by a strange loop: in a strict sense, the effect or consequence precedes its cause, for a cause can only emerge through the working out of a historical sequence. For it can only be a cause once its "consequences" are played out - a process which, of course, changes again and again, giving the connections of historical cause and effect their necessary indeterminacy. But this does not mark a "consequentialist" account of the event, for in a peculiar way the forces released by the event also have to be grasped as immanent to the event itself. The expectations, fears, hopes, and claims generated by the event in the medium or long term are thus both external to the event (they crystallize in its wake) and internal to it (the structure of the event itself, in its immediacy, stages many of its future appropriations and "consequences").

To grasp the plague as an "event" in the history of Bombay's labour relations, then, so far from being an insight transparently offered up by the available historical sources, is a conscious interpretive choice which needs to be worked through, conceptually as well as narratively. In contrast to the general appreciation of the plague's significance for Bombay's larger social history, its remarkable effects on the city's labour relations have in the main received only muted recognition. My hypothesis is that by restoring the "eventual" significance of the plague, we might achieve a significantly new narrative of labour relations in the medium and long term as well. The formulations which follow, and which conclude this essay, seek to open up some ground for this.

94. See, for instance, Alain Badiou, Theoretical Writings (London 2004), ch. 8; and idem, Being And Event (London, 2005).

95. Slavoj Žižek's reflections on the theme of the event span most of his career, and his formulations have changed from context to context. But the main line of argument, which is consistent and scattered across a typically bewildering range of enquiries, is perhaps best worked out in Slavoj Žižek, The Ticklish Subject: The Absent Centre of Political Ontology (London, 1999), ch. 3; in his magnum opus, Less Than Nothing: Hegel and the Shadow of Dialectical Materialism (London, 2012); and in a recent volume, relatively minor but nevertheless stimulating, entitled Event: Philosophy in Transit (London, 2014). 
First of all, the plague crisis clarified the social relations of authority and subordination upon which Bombay's urban order rested. Paradoxically, though, these relations achieved this crystalline clarity - as visible to contemporary observers as to future scholars - only at the point of their possible breakdown. With millworkers, as well as with other classes of urban labour, it was the very rupture of employment relations that revealed the structural patterns of social power in their starkest form. In the mills, the wage-arrears system, prior to the intrusion of the plague, had been grasped as merely one element of many that made up the relations between employers and workers. The collapse of wage-arrears, however, profoundly ruptured the hierarchies of the employment relationship. In this altered context, a new historical "truth" became apparent to contemporaries: the cycle of arrears and debt was revealed as the very heart of the social relations upon which the city's reproduction rested, without which the employment form - and the urban form - could simply not be sustained in their "normal" shape. It is not simply that the plague made the structuring role of the wage-arrears system "visible". It is, rather, that the specific character of the plague crisis not only revealed but actively produced the centrality of this structure, as a problem that employers, state, and workers actively needed to negotiate and fight over.

Simultaneously, however, the plague crisis reconstituted relations of capitalist authority in the mills (as well as other work sites and regimes) in a new key. As employers subsumed many of the functions of social reproduction by moving to control labour supply, credit, housing, and food provisioning (functions that had hitherto nested in the "informal" relations of neighbourhood and community), new images and practices of industrial relations were momentarily forged. In the short term, these proved evanescent: as the initial crisis of the labour market faded and workers returned to the mills, older structures of control could be restored - but only up to a point. Since the plague crisis introduced a hitherto unimaginable structure of workplace relations - which I have characterized as "regulation from below" - the existing instruments of employer domination could no longer be taken for granted. Much of the subsequent history of Bombay's mills was to consist of the elaboration of forms of social welfare and reproduction, of labour supply and control, which were far more tightly and consciously regulated by both employers and the state.

Moreover, the new constellations of relations of production and social reproduction emergent in the early twentieth century were also, especially after World War I, to be punctuated by major episodes of strike action and workers' collective resistance. Wage arrears as an instrument of control would eventually disappear, in mill after mill. Bonuses, initially conceived as an emergency concession, would become regularized as a 
right workers commanded. Mills would come to provide canteens, grain shops, housing, provident funds, and the like on a far more general scale than before. In other words, temporary concessions made during the plague towards workers - and also towards a more direct, unmediated employer-employee relationship - would stabilize, in subsequent decades, as dominant forms.

This might appear as a simple point about the "consequences" of the plague crisis, but there is a twist. In the first place, to speak of "consequences" is perhaps to deploy the wrong model of causality for the plague-as-event, given that many of these modifications of the institutions of social reproduction happened decades after the epidemic and cannot be traced back to it in any linear fashion. (In the case of the reforms effected by the Bombay Improvement Trust, especially with regard to housing, the causal links are clearer). However, the plague crisis foreshadowed many of the future social compromises that were to be hammered out between employers, state, and workers over decades of intense class struggle and negotiation. As such, the event anticipated the shape of much of the future, without in any direct way producing it.

The crystallization, shattering, reconstitution, and foreshadowing of urban social structures and relations: these, then, were the modalities of the plague crisis as a historical event. Absolutely immanent to a very specific and bounded historical situation, it exceeded it both in its immediacy and in its legacies. As such, the brief period between I 896 and I 898 occupies a strange and disjointed relationship to its conditions of emergence. Materially and ideologically embedded in its time, the event, nevertheless, was its own creature, in peculiar and paradoxical ways. It constituted a point where the past (of the city and its labour relations), the present (of absolute social crisis), and the future (of new and emergent social structures) met. It is the simultaneity of these different logical "moments" which gives the plague crisis its character as historical event.

TRANSLATED ABSTRACTS

FRENCH - GERMAN - SPANISH

Aditya Sarkar. Le lien qui se rompit. Peste bubonique et travail en usine textile à Bombay, I 896-I898.

En septembre 1896 , la ville de Bombay assista au début d'une longue crise épidémique persistante, lorsque la peste bubonique se déclara. Cet article examine une dimension particulière de cette crise - soit ses effets sur les usines textiles cotonnières de la ville et son altération profonde, bien que temporaire, des relations entre employeurs et travailleurs. L'article soutient que la structure des relations industrielles dans les usines textiles pendant la seconde moitié du dix-neuvième siècle 
reposa sur la retenue des arriérés de salaires par la direction des usines, ce qui força les travailleurs à s'endetter constamment et les lia à l'usine et à leur employeur. Comme le montre l'article, la crise démographique et industrielle amorcée dans les années de la peste rompit brusquement cette structure de contrôle industriel, et les travailleurs parvinrent à maintenir un nouveau système éphémère de "réglementation du travail depuis la base", fondé sur le paiement quotidien des salaires. Étudiant les tensions dans les usines textiles en i 897 dans le contexte élargi d'une crise des relations de travail urbaines, l'article montre comment les relations industrielles furent décomposées et reconstituées sous une nouvelle forme.

Traduction: Christine Krätke-Plard

Aditya Sarkar. Das Band, das riss. Beulenpest und Baumwollindustrie in Mumbai, I 896-I 898 .

Im September I 896 erlebte die Stadt Mumbai mit dem Ausbruch der Beulenpest den Beginn einer sich lang hinziehenden Krise. Der Beitrag untersucht einen bestimmten Aspekt dieser Krise: ihre Auswirkungen auf die Baumwollspinnereien der Stadt und ihre tiefgreifende, wenn auch nur vorübergehende Veränderung der Beziehungen zwischen Arbeitgebern und Arbeitern. Es wird die These vertreten, dass die Arbeitsbeziehungen in den Baumwollspinnereien auf dem Aufschub der Lohnzahlungen durch die Geschäftsführer beruhten, was die Arbeiter zur ständigen Verschuldung zwang und sie damit an die Spinnerei und an ihre Arbeitgeber band. Die demographische Krise und die Industriekrise, die durch die Jahre der Beulenpest eingeleitet wurden, ließen dieses Verfahren zur Kontrolle der Belegschaft brüchig werden, wie der Beitrag zeigt: Die Arbeiter waren in der Lage, innerhalb ihrer Industrie ein neues, allerdings nicht dauerhaftes System der "Regulierung von unten” zu etablieren, das auf täglichen Lohnzahlungen beruhte. Ausgehend von einer Studie der Spannungen, zu denen es I897 in den Baumwollspinnereien kam, und zwar im Kontext einer umfassenderen Krise städtischer Arbeitsbeziehungen, zeigt der Artikel, auf welche Weise die Arbeitsbeziehungen sowohl zersetzt als auch in veränderter Form wiederhergestellt wurden.

Übersetzung: Max Henninger

Aditya Sarkar. El lazo que se rompió. La peste bubónica y el trabajo en la algodoneras de Bombay, I896-I898.

En septiembre de i 896 la ciudad de Bombay fue testigo del comienzo de una crisis epidémica de larga duración con el estallido de la peste bubónica. En nuestro artículo se investiga una de las dimensiones particulares que podemos observar en esta crisis: sus efectos sobre los centros de producción de algodón existentes de la ciudad y su profunda, aunque temporal, alteración de las relaciones existentes entre los patronos y sus trabajadores. En el texto se plantea que la estructura de las relaciones industriales en las algodoneras a lo largo de la segunda mitad del siglo XIX descansaba sobre la retención de salarios atrasados por los administradores de las fábricas, lo que forzaba a los trabajadores a adentrarse en una permanente 
espiral de endeudamiento, además de servir para su sujeción a la fábrica y a sus propietarios. En nuestro análisis podemos observar como la crisis demográfica e industrial que acompañó durante los años de la epidemia resquebrajó esta estructura de control industrial y los trabajadores tuvieron la posibilidad de establecer de forma fugaz unas nuevas formas de "regulación industrial desde abajo" basadas en el pago diario de sus salarios. A través del estudio de las tensiones habidas en las industrias algodoneras en I 897, ubicadas en el contexto más extenso de una crisis de las relaciones laborales urbanas, el artículo muestra las vías por las que las relaciones industriales se fueron descomponiendo y se reconstituyeron en un sentido diferente al existente.

Traducción: Vicent Sanz Rozalén 